NBER WORKING PAPER SERIES

\title{
DOOMED TO DEFICITS? \\ AGGREGATE U.S. TRADE FLOWS RE-EXAMINED
}

\author{
Menzie D. Chinn \\ Working Paper 9521 \\ http://www.nber.org/papers/w9521 \\ NATIONAL BUREAU OF ECONOMIC RESEARCH \\ 1050 Massachusetts Avenue \\ Cambridge, MA 02138 \\ February 2003
}

I thank Yin-Wong Cheung, Neil Ericsson, Hamid Faruqee, Joe Gagnon, Bill Helkie, Catherine Mann and Jaime Marquez for useful comments and Robert Z. Lawrence for many helpful discussions at the inception of this project. Olivier Coibion provided excellent research assistance. Part of this work was conducted while the author was senior staff economist at the Council of Economic Advisers. Faculty research funds of the University of California are also gratefully acknowledged. The views expressed herein are those of the author and not necessarily those of the National Bureau of Economic Research, or any other organizations the author has been affiliated with.

(C)2003 by Menzie D. Chinn. All rights reserved. Short sections of text not to exceed two paragraphs, may be quoted without explicit permission provided that full credit including Cnotice, is given to the source. 
Doomed to Deficits? Aggregate U.S. Trade Flows Re-Examined

Menzie D. Chinn

NBER Working Paper No. 9521

February 2003

JEL No. F31, F41

\title{
$\underline{\text { ABSTRACT }}$
}

This paper examines the stability of import and export demand functions for the United States over the 1975q1-2001q2 period. Using the Johansen maximum likelihood approach, an export demand function is readily identified. In contrast, there appears to be a structural break in the import demand function in 1995; specifications incorporating this break pass tests for cointegration, although the price elasticity is not statistically significant. Only when excluding computers and parts from the import series is a stable import demand function detected. The resulting point estimates do not exhibit the income asymmetry typically found in other studies of aggregate U.S. trade flows.

\author{
Menzie D. Chinn \\ Department of Economics \\ University of California \\ Santa Cruz, CA 95064 \\ and NBER \\ chinn@ucsc.edu
}




\section{Introduction}

This paper examines the relationship between U.S. aggregate trade flows, real exchange rates and incomes. While this literature has a long and venerable history, a reexamination is justified, as some of the most recent work on this subject cast doubt on the existence of a stable link between relative prices and trade flows. Moreover, the burgeoning U.S. trade deficit (illustrated in Figure 1) has imparted some urgency to the mission of estimating the empirical determinants of trade flows; in particular, interest is focused on whether the well-known income elasticity asymmetry first noted by Houthakker and Magee (1969) persists. Some observers have pinned hopes for stabilizing the trade deficit on a convergence of the income elasticities of the U.S. and her trading partner economies, combined with accelerated growth in the rest of the world.

The analysis relies upon the Johansen procedure, which is used to determine whether cointegrating relations exist, and how trade flows respond to deviations in long run relationships. Special attention is focused on how the results differ depending upon the exact measure of the exchange rate used and the composition of the trade variable examined. Three measures are examined - consumer price index (CPI), a producer price index (PPI) and unit labor cost (ULC) deflated indices - as each one exhibits somewhat different behavior.

The results indicate that there is a statistically significant relationship between total exports of goods and services, U.S. income and the real exchange rate. The unit labor cost deflated measure of the dollar yields the strongest evidence of cointegration. However, for U.S. imports, there appears to be little evidence of cointegration. Only by 
allowing for a structural break in 1995 does one obtain some evidence of a long run relationship. Delving further, I find that use of non-computer imports yields a satisfactory fit without resort to the use of intervention dummies. Furthermore, once the quantity of non-computer imports is made the variable of interest, the famous income elasticity asymmetry of Houthakker and Magee (1969) disappears. ${ }^{1}$

\section{Theory and literature review}

The empirical specification is motivated by the traditional, partial equilibrium view of trade flows. Goldstein and Khan (1985) provide a clear exposition of this "imperfect substitutes" model. To set ideas consider the algebraic framework that Rose (1991) uses. Demand for imports in the US and the Rest-of-the-World (RoW) is given by:

$$
\begin{aligned}
& D_{i m}^{U S}=f_{1}^{U S}\left(Y^{U S}, P_{i m}^{U S}\right) \\
& D_{i m}^{R o W}=f_{1}^{R o W}\left(Y^{R o W}, P_{i m}^{R o W}\right)
\end{aligned}
$$

where $P_{i m}$ is the price of imports relative to the economy-wide price level. The supply of exports is given by:

$$
\begin{aligned}
& S_{e x}^{U S}=f_{2}^{U S}\left(P_{e x}^{U S}\right) \\
& S_{e x}^{R o W}=f_{2}^{R o W}\left(P_{e x}^{R o W}\right)
\end{aligned}
$$

\footnotetext{
${ }^{1}$ This study is not the first one to provide an explanation for the income asymmetry. Helkie and Hooper (1988) argue that inclusion of relative supply, via a relative capital stock measure, makes the gap in elasticities disappear. Arora et al. (2001) obtain estimates income elasticities that appear to be converging. They interpret these results in the context of the Krugman (1989) model, where these income elasticities are actually functions of income growth rates.
} 
Note that the price of imports into the US is equal to the price of foreign exports adjusted by the real exchange rate.

$$
P_{i m}^{U S}=E \times P_{e x}^{R o W}=Q P_{e x}^{R o W}
$$

where $E$ is the nominal exchange rate in US\$ per unit of foreign currency, and the real exchange rate is

$$
Q=\frac{E P^{R o W}}{P^{U S}}
$$

where $P$ represents the aggregate level of prices. An analogous equation applies for imports into the rest-of-the-world. Imposing the equilibrium conditions that supply equals demand, then one can write out import and export equations (assuming log-linear functional forms):

$$
\begin{aligned}
& i m_{t}=\beta_{0}+\beta_{1} q_{t}+\beta_{2} y_{t}^{U S}+\varepsilon_{2 t} \\
& e x_{t}=\delta_{0}+\delta_{1} q_{t}+\delta_{2} y_{t}^{R o W}+\varepsilon_{1 t}
\end{aligned}
$$

where $\delta_{1}>0$ and $\delta_{2}>0$ and $\beta_{1}<0$ and $\beta_{2}>0$.

One can interpret equations (6) and (7) as semi-reduced form equations. Consider equation (6); this expression collapses the relationship between the relative import price and imports (equation 1) and the relationship between the exchange rate and relative prices (equation 5) into one equation. To the extent that one takes the real exchange rate as "more exogenous" than the relative price of imports, this approach makes more sense 
when the economic question at hand is "what is the response of imports to a one percent change in the real exchange rate?" 2

The literature on trade equations is vast, and no survey can do justice to the variety of findings that have been obtained. In this review, I focus on those studies conducted in the cointegration framework, largely because the earlier econometric literature pertains to much earlier data samples.

Rose and Yellen (1989) estimated regressions of the general form of (6) and (7), but focused on the trade balance. They examined monthly data over the 1960-85 period, and failed to detect evidence of cointegration using the Engle-Granger procedure. Hence, they estimated a first difference specification using instrumental variables and failed to find a substantial effect of relative prices on the trade balance. For our purposes, the important point is that this finding held up to disaggregation to individual import and export flows.

Meade (1992) provides a useful update to the Rose and Yellen results. Using the Engle-Granger cointegration methodology, she found that extending the analysis to quarterly data from 1970 through 1991 yielded more favorable results. Real nonagricultural exports appear to be borderline cointegrated with the real exchange rate and income. Meade's results differ from Rose and Yellen's largely because of the difference in sample period, which spanned the reduction in the trade deficit in the late 1980's. However, imports failed to exhibit evidence of cointegration.

\footnotetext{
${ }^{2}$ This specification has the additional drawback that it does not fulfill the assumption of homogeneity in prices. In contrast, a specification including the relative price of imports (or exports) to the GDP deflator would fulfill this condition. As long as the ratio of the GDP deflator to the alternative deflators I use does not have a large stochastic trend, then the use of this specification may not do too much violence to the data.
} 
Recent work has relied on more powerful econometric techniques, such as the multivariate maximum likelihood estimation procedure of Johansen (1988). In conjunction with additional data, this procedure has provided more evidence of cointegration than obtained in previous studies. Johnston and Chinn (1996) find evidence of a long run relationship between trade flows, incomes and the real exchange rate over the 1973-93 period. Boyd et al. (2001) examine the behavior of the trade ratio (the log of real exports divide by real imports) over the 1970-94 period and find evidence of cointegration, although the specification they use constrains the import and export elasticities to be equal and opposite in sign.

The analysis most closely related to this one is an exhaustive study conducted by Hooper et al. (1998). They find evidence of cointegration for both U.S. exports and imports over the 1960-1994 period, using relative prices (either import or export prices relative to broad deflators) or a real effective exchange rate. Interestingly, they obtain an incorrect sign for the price elasticity for imports when using a real effective exchange rate index. That is, a weaker dollar is associated with greater imports, according to their results. $^{3}$

They also confirm that the income asymmetry first noted by Houthakker and Magee persists in their sample. Income elasticities for imports exceed those of exports by about 0.4 to 0.5 .

\footnotetext{
${ }^{3}$ It should be noted that Hooper et al. (1998) focused their attention on results using relative prices (e.g., the price of imports relative to the general price deflator), rather than those relying upon real exchange rates. Those price elasticity estimates were typically larger than the corresponding ones based on real exchange rates.
} 


\section{Data and Estimation}

\subsection{Data $^{4}$}

For measures of trade flows, data on real imports and exports of goods and services (1996 chain weighted dollars) were obtained. These series are depicted in Figure 2. Additional data on real imports and exports of non-computer goods and services were also compiled. While the focus of this study is aggregate trade flows, I have also examined selected disaggregate trade flows (goods and services separately). These results are reported in Appendix 2.

Domestic economic activity was measured by U.S. GDP in 1996 chain weighted dollars. Foreign economic activity was measured by Rest-of-World GDP (expressed in 1996 dollars). This measure rest-of-world GDP is weighted by U.S. exports to major trading partners.

Three different exchange rate indices were utilized. The first was the most ubiquitous - the Federal Reserve Board's major currencies trade weighted exchange rate. This index uses the CPI as the deflator. The second is the J.P. Morgan broad tradeweighted real exchange rate, deflated using the PPI. Finally, the IMF's trade-weighted real exchange rate deflated using unit labor costs. All three series are shown in Figure 3 (rescaled to equal 0 in 1973q1). ${ }^{5}$ Additional details on all these variables are contained in the Appendix 1.

\footnotetext{
${ }^{4}$ The data are described in further detail in Appendix 1.

5 The various exchange rate indices also differ in terms of their construction. The Fed index uses time varying trade weights, while the J.P. Morgan index uses fixed trade weights, with one discrete change in the weights. The IMF series uses fixed trade weights, although in using a spliced series in this analysis, a change in trade weights is artificially introduced. Both the Fed and IMF series account for third market effects using
} 
The first two indices approximate measures of "price competitiveness". Of these, the CPI-deflated measure is probably the least desirable on a priori grounds since it incorporates the prices of many non-traded goods that are unlikely to be relevant to flows of traded goods (although they might be indicative of costs of services).

The third measure merits some more detailed discussion. The unit labor cost deflated measure is best thought of as an empirical proxy for "cost competitiveness". It is an imperfect measure, at best, measuring labor costs, rather than total costs. To see how this variable is related to the PPI based index, consider a markup model of pricing:

$$
p_{t}^{T}=\log \left[(1+\mu)\left(\frac{W_{t}}{A_{t}}\right)\right]
$$

where $p^{T}$ is the log nominal price of tradable goods, $\mu$ is percentage markup, $W$ is the nominal wage rate, $A$ is labor productivity per hour. $W / A$ is therefore unit labor cost. Reexpressing the real exchange rate

$$
q_{t}=e_{t}-p_{t}^{U S}+p_{t}^{R o W}
$$

using equation (8) for prices yields:

$$
q_{t}^{U L C}=e_{t}-\left(w_{t}^{U S}-a_{t}^{U S}\right)+\left(w_{t}^{R o W}-a_{t}^{R o W}\right)
$$

the Armington assumption. See Chinn (2002) for a detailed discussion of the characteristics of these indices. 
(holding markups constant). In this case, the real exchange rate is the nominal rate adjusted by wages and productivity levels. As productivity levels rise, the real dollar cost of production falls, while rising wages cause an appreciated real dollar. This definition of the real exchange rate also fits in with a Ricardian model of trade (Golub, 1994).

\subsection{Estimation}

Estimation is implemented on data spanning a period of 1975q1-2001q2. This period spans two episodes of dollar appreciation and two episodes of dollar depreciation. Truncation to $2001 \mathrm{q} 2$ is motivated by the desire to omit possible distortions in the trade flow relationships due to the events of $9 / 11$.

Estimation proceeds in two steps: (1) Lag length selection and (2) estimation of the vector error correction model (VECM). The latter step entails interpretation of the cointegration results, and examination of the short run dynamics.

The lag length is determined by the minimum AIC for the unconstrained VAR, with the lag lengths of up to 8 lags considered. In all cases, the 2 lag specification yields the minimum AIC.

The Johansen (1988) and Johansen and Juselius (1990) maximum likelihood procedure is implemented in order to test for cointegration and identify the cointegrating vector. For the import system, the procedure estimates the following vector error correction model: ${ }^{6}$

\footnotetext{
${ }^{6}$ For expositional simplicity, I have assumed only one cointegrating relationship per system; in fact neither theory nor econometric technique requires this condition.
} 


$$
\begin{aligned}
& \Delta i m_{t}^{U S}=\gamma_{10}+\varphi_{1}\left(i m_{t-1}^{U S}-\beta_{1} q_{t-1}-\beta_{2} y_{t-1}^{U S}\right)+\gamma_{11} \Delta i m_{t-1}^{U S}+\gamma_{12} \Delta q_{t-1}+\gamma_{12} \Delta y_{t-1}^{U S}+\varepsilon_{1 t} \\
& \Delta q_{t}=\gamma_{20}+\varphi_{2}\left(i m_{t-1}^{U S}-\beta_{1} q_{t-1}-\beta_{2} y_{t-1}^{U S}\right)+\gamma_{21} \Delta i m_{t-1}^{U S}+\gamma_{22} \Delta q_{t-1}+\gamma_{23} \Delta y_{t-1}^{U S}+\varepsilon_{2 t} \\
& \Delta y_{t}^{U S}=\gamma_{30}+\varphi_{3}\left(i m_{t-1}^{U S}-\beta_{1} q_{t-1}-\beta_{2} y_{t-1}^{U S}\right)+\gamma_{31} \Delta i m_{t-1}^{U S}+\gamma_{32} \Delta q_{t-1}+\gamma_{33} \Delta y_{t-1}^{U S}+\varepsilon_{3 t}
\end{aligned}
$$

For exports, the system estimated is:

$$
\begin{aligned}
& \Delta e x_{t}^{U S}=\gamma_{40}+\varphi_{4}\left(e x_{t-1}^{U S}-\delta_{1} q_{t-1}-\delta_{2} y_{t-1}^{R o W}\right)+\gamma_{41} \Delta e x_{t-1}^{U S}+\gamma_{42} \Delta q_{t-1}+\gamma_{43} \Delta y_{t-1}^{R o W}+\varepsilon_{4 t} \\
& \Delta q_{t}=\gamma_{50}+\varphi_{5}\left(e x_{t-1}^{U S}-\delta_{1} q_{t-1}-{ }_{2} y_{t-1}^{R o W}\right)+\gamma_{51} \Delta e x_{t-1}^{U S}+\gamma_{52} \Delta q_{t-1}+\gamma_{53} \Delta y_{t-1}^{R o W}+\varepsilon_{5 t} \\
& \Delta y_{t}^{R o W}=\gamma_{60}+\varphi_{6}\left(e x_{t-1}^{U S}-\delta_{1} q_{t-1}-\delta_{2} y_{t-1}^{R o W}\right)+\gamma_{61} \Delta e x_{t-1}^{U S}+\gamma_{62} \Delta q_{t-1}+\gamma_{63} \Delta y_{t-1}^{R o W}+\varepsilon_{6 t}
\end{aligned}
$$

Two test statistics for testing the alternative of cointegration against the null of no cointegration are calculated: the trace and the maximum eigenvalue statistic. Both are referred to, although generally they will agree on the existence of a cointegrating relationship, and the number of cointegrating vectors. ${ }^{7}$

There are also additional specification issues related to the allowance for constants and trend terms in either the data or the cointegrating vector. For most of the specifications, the AIC selects a model with deterministic trends allowed in the data, but not in the cointegrating vector. ${ }^{8}$

\footnotetext{
${ }^{7}$ Cheung and Lai (1993) have shown that it is often important to account for degrees of freedom when using highly parameterized VARs. However, with the short lag lengths implemented and relative parsimony of the specifications, the conclusions would be unchanged using finite sample critical values.
}

${ }^{8}$ See Chapter 8 of Banerjee, et al. (1993) for additional discussion. 
The procedure provides estimates of the long run coefficients (the $\beta$ 's and $\delta$ 's) as well as the reversion coefficients (the $\varphi$ 's). The reversion coefficients are of interest for a number of reasons. First, the reversion coefficients on the trade flows should be negative, and statistically significant, indicating that imports and exports respond to a disequilibrium in the cointegrating relationship by closing the gap. Second, to the extent that one would like to interpret the estimated coefficients as it would be useful to be able to interpret the trade flows as responding to exogenous movements in the other variables, while the reverse is not true. Technically speaking, this is equivalent to weak exogeneity of these two variables, i.e., statistically insignificant reversion coefficients for the exchange rate and income.

\subsection{Empirical Results}

Table 1 reports the results for imports of goods and services. In column 1, results are shown for the specification incorporating the CPI deflated real exchange rate. The trace and maximum eigenvalue statistics do not indicate evidence for cointegration, even at the $10 \%$ marginal significance level.

Imports accelerate in the mid-1990's, roughly contemporaneously with the acceleration in trend GDP growth. Thus, it makes sense to account for a possible structural break in 1995q1. This is accomplished by including an (exogenous) dummy at this date. The results for this specification are shown in column 2 . There is now evidence of cointegration, at the $10 \%$ level according to the trace statistic, and at the $5 \%$ level according to the maximum eigenvalue statistic. The long run income elasticity is 
substantial, at 2.1, while the price elasticity estimate is correctly signed but not statistically significant.

The reversion coefficients in the lower panel of Table 1 indicate that imports respond to disequilibria in the long run import relationship, at a rate of about $18 \%$ per quarter. The real exchange rate responds, albeit more slowly, and with borderline statistical significance. GDP does not respond at all, a finding consistent with weak exogeneity of the income variable. ${ }^{9}$

Similar results are obtained using a PPI deflated measure of the real exchange rate. There is little evidence of cointegration over the entire sample (column 3). However, when allowance is made for a break in 1995, then there is strong evidence of cointegration. ${ }^{10}$ In this case the price elasticity is statistically significant. Imports and the real exchange rate respond to the long run disequilibrium. However, it should be noted that the long run price elasticity of imports is quite low: 0.18 . This estimate is substantially below what is conventionally perceived as the sensitivity of imports to exchange rates. ${ }^{11}$

The analogous regression results for exports of goods and services are reported in Table 2. Overall, the results are much more favorable toward a finding of cointegration. There is no need to allow for a structural break in order to make this conclusion. The

\footnotetext{
${ }^{9}$ While weak exogeneity is discussed informally in terms of the t-statistics on the adjustment coefficients, formal likelihood ratio test statistics typically concur (Johansen and Juselius, 1990).

${ }^{10}$ A caveat is necessary here. The critical values used are based on the absence of exogenous dummy variables. Accounting for these dummies would likely reduce the statistical significance of the results.

${ }^{11}$ As pointed out by Bill Helkie, another potential reason for the difficulty in detecting evidence for cointegration is the inclusion of oil imports in the aggregate. I reserve this avenue of inquiry for future work.
} 
sensitivity of exports to the real exchange rate is between 0.7 to 0.8 when using the CPI deflated measure, and slightly higher -0.8 to 0.9 - when using the PPI deflated measure. Overall, income elasticity estimates are relatively robust. They range from 1.7 to 2 .

The reversion coefficients indicate that it is only export flows that respond to disequilibria in the long run export relationship. In other words, the real exchange rate and foreign income are weakly exogenous for exports. Depending upon the deflator used, the rate at which exports respond ranges from $10 \%$ to $17 \%$ per quarter.

One implication of the exchange rate coefficient estimates is that the MarshallLerner condition only barely holds even in the long run; the sum of the (absolute value of the) point estimates is just over unity. If one takes into account the fact that the import price elasticity is not statistically significant, then the trade balance does not improve in response to an exchange rate depreciation.

As previously discussed, the CPI and PPI deflated real exchange rates conform to the concept of "price competitiveness", while the unit labor cost deflated measure is more closely linked to "cost competitiveness". Import and export regression results are reported in Table 3. Column 1 indicates that there is little evidence of cointegration over the entire sample, using this real exchange rate index. Column 2 provides more promising results - evidence of cointegration is found. However, the price coefficient is not statistically significant, indicating no long run response of imports to the real exchange rate, even after allowing for a structural break.

This is a somewhat surprising result. Typically, one would think that unit labor costs should be strongly related to trade flows. One possible reason for the weakness of the link is that this measure focuses on trading patterns and productivity trends of other 
industrial countries (Zanello and Desruelle, 1997), and import sources are oriented slightly more towards LDCs than are export destinations. ${ }^{12}$

In contrast, there does appear to be a stable long run export relationship using this, or any of the other, real exchange rate indices. The price elasticity is somewhat less than identified using the other measures. In this case, the price elasticity is 0.5 to $0.6 \mathrm{vs}$. the 0.7 to 0.9 . The income elasticity also appears to be somewhat lower too. On the other hand, the reversion rate is more rapid, at roughly $23 \%$ per quarter. ${ }^{13}$

\section{Interpreting the Structural Break}

From an econometric standpoint, allowing for a structural break in the import equation is successful. However, the result is unsatisfying from an economic perspective. In particular, one does not know the cause of the break; consequently, one does not know if the effect will be reversed. This particular issue is of importance because the intervention dummy manifests itself as a larger drift term in the error correction model. If this shift is permanent, then imports far outstrip exports, even when U.S. and Rest-ofWorld income grow at the same rate, and the exchange rate stays constant.

Another perspective on the role of the shift dummy is that it is capturing the effect of mis-specification. One particular form of mis-specification is suggested by previous empirical work finding that imports of computers, peripherals and parts are particularly

\footnotetext{
${ }^{12}$ Furthermore, unit labor costs are probably subject to greater measurement errors, as they are quite difficult to measure.

${ }^{13}$ These findings extend to disaggregated data to a limited extent. The results in Appendix 2 indicate that it evidence of a cointegrating relationship for goods exports is readily obtained, but a similar conclusion does not hold for services exports. As anticipated the real exchange rate elasticity for goods exports is typically higher than the corresponding elasticity for goods and services exports.
} 
difficult to model. Lawrence (1990) and Meade (1991) were the first to observe that stripping out these components was useful in obtaining a stable relationship. As discussed in CEA (2001), trade in computers and semiconductors boomed in recent years, rising from about $3.5 \%$ in 1990 to $6 \%$ in 2000 (their role in exports is much smaller). At this same time, the real price of computers and parts has fallen dramatically, implying a large drop in the relative price. The time series behavior of log total imports and computers, in chained 1996\$, is shown in Figure 4. It is apparent that the real magnitudes differ in trends substantially, so that aggregating computer and non-computer trade data may be unjustified.

In Table 4, estimates are reported using imports of goods and services excluding computers, over the 1975q1-2000q3 period. In column 1, the results of testing for a long run relationship between non-computer imports, the PPI deflated real exchange rate, and U.S. GDP, are reported. The results are not encouraging, as little evidence of cointegration is detected. A similar story is told by the results in column 2, where the PPI deflated exchange rate variable has been replaced by the unit labor cost deflated index.

The robustness of the results to alternative lag specifications is assessed in column 3. The lag length is increased to 4 (consistent with quarterly data). The AIC selects a specification with a trend in the cointegrating vector. The results are implausible, however. First, two cointegrating vectors are indicated. Second, the income elasticity is implausibly large. Each one percent increase in U.S. GDP increases imports by 15 percent! The trend term appears to be picking up much of the movement in imports; the coefficient implies imports increase by 13 percent each quarter. 
In column 4, I report the results of a specification where the trend is restricted to exist only in the data (that is, the same specification as in Tables 1-3). The AIC in this case is -15.90 vs. -15.97 for the previous specification, so the fit is still adequate, relative to that of column 3. Note the Schwartz Information Criterion indicates a tie between the two.

The results from this specification indicate evidence for cointegration according to both the trace and maximum eigenvalue statistics. The income elasticity is in line with the estimates in Tables 1 and 3, while the price elasticity, while small, is more plausible, and statistically significant. Interestingly, in this case we reverse the finding of Hooper et al. (1998), who found that the real exchange rate measure had the wrong sign. These results suggest that non-computer imports are related in a stable fashion to the real exchange rate and GDP. A similar finding is obtained when using non-computer imports of goods; as shown in Table A1 in Appendix 2, only the non-computer category of goods imports appears cointegrated with the real exchange rate and income. Goods imports as whole do not exhibit evidence of a long run relationship with theses variables. Moreover, the estimated elasticities for non-computer goods imports are similar to those for noncomputer goods and services imports. ${ }^{14}$

In contrast, real computer imports are quite difficult to model. AIC statistics from VARs indicates a 2 lag structure is appropriate. Among various model specifications, the AIC selects a quadratic trend in the data. Estimation of this model yields ample evidence of cointegration, with a very large income elasticity of 2.6. The point estimate for the real

\footnotetext{
${ }^{14}$ It is standard to subject estimated models to out-of-sample forecasting tests. I have not conducted a formal test of structural stability; however, Appendix 3 provides a discussion of the out-of-sample forecasting ability of the specifications estimated.
} 
exchange rate is incorrectly signed - it is 1.4 , indicating that a one percent depreciation increases imports of computer parts.

Almost certainly, this result is a reflection of the fact that the PPI deflated real exchange rate used here gives too little weight to the prices for computers and parts, given the dependent variable is the quantity of computer imports. For illustrative purposes, Figure 5 depicts the trends in the chain price deflator for U.S. computer imports, and the U.S. PPI.

\section{Conclusions and Re-Interpretation}

There are several significant findings to be gleaned from this analysis. First, a stable long run relationship exists for U.S. exports, the real exchange rate and rest-of-world income. The evidence for cointegration is particularly strong for a real exchange rate measure constructed using unit labor costs. The finding of a stable export relationship is not dependent upon allowance for a structural break.

In contrast, aggregate U.S. imports are quite difficult to model, regardless of the real exchange rate measure used. Only by allowing for a structural break in 1995q1 can some evidence for cointegration be found. However, even in this case, the price elasticity is economically small and statistically insignificant.

Aggregate imports excluding computers, peripherals and parts do, however, appear to be related to the real exchange rate and income, in a stable fashion. In contrast, I cannot isolate a plausible demand function for imports of computers. The exchange rate coefficient is invariably wrong-signed, while income picks up a large proportion of the variation. 
It may be useful to summarize at this point what has been learned in revisiting this subject. Regarding the adjustment process for U.S. trade flows, these results provide a different set of lessons than that drawn from previous studies. Consider Table 5. In the top panel, import estimates are reported. The estimate of non-computer import price elasticity in column (4) is correctly signed, in contrast to those obtained by Hooper et al. using an exchange rate index. However, it is substantially smaller than the estimate obtained by Boyd et al. from their (constrained) Johansen estimation procedure. The estimated income elasticity appears much in line with those obtained by Hooper et al., and most other studies (see Mann, 1999, Table 8.2; Lawrence, 1990).

On the export side, the estimated export price and income elasticities are somewhat higher than those reported by Hooper et al., as long as the PPI deflated measure is used. The results in column 4 indicate that when using the same exchange rate index as Hooper et al. used, the point estimates are essentially the same as theirs.

One interesting conclusion of this study is that the asymmetry in income elasticities, first pointed out by Houthakker and Magee (1969), may no longer be as pronounced as is typically thought. The income elasticity of export demand estimated when using the PPI-deflated real exchange rate is the same as that of non-computer imports. ${ }^{15}$ Hence, it appears that including real computer imports into the import aggregate provides a potentially misleading impression of price and income elasticities.

\footnotetext{
${ }^{15}$ These income elasticity estimates still deviate from the value of unity implied by the standard imperfect substitutes model, combined with the assumption that traded goods are normal goods. However, relaxing any number of assumptions can lead to non-unitary elasticities, including trade in intermediate goods, or increasing returns to scale production. See Hong (1999) for a recent survey.
} 
One last finding of interest is that the import price elasticity remains quite low. This finding suggests that improvements in the U.S. trade balance may require large movements in the value of the dollar, especially when starting from an initial position of deficit. 


\section{References}

Arora, Vivek, Steven Dunaway and Hamid Faruqee, 2001, "Chapter II: Sustainability of the U.S. External Current Account Deficit," United States: Selected Issues, IMF Country Report No. 01/149 (Washington, DC: IMF, August).

Bannerjee, Anindya, Juan Dolado, John W. Galbraith and David Hendry, 1993, Cointegration, Error Correction, and the Econometric Analysis of Non-Stationary Data (Oxford: Oxford University Press).

Boyd, Derick, Guglielmo Maria Caporale and Ron Smith, 2001, "Real Exchange Rate Effects on the Balance of Trade: Cointegration and the Marshall-Lerner Condition," International Journal of Finance and Economics 6: 187-200.

Cheung, Yin-Wong and Kon. S. Lai, 1993, "Finite-Sample Sizes of Johansen's Likelihood Ratio Tests for Cointegration," Oxford Bulletin of Economics and Statistics 55(3): 313-328.

Chinn, Menzie, 2002, "The Measurement of Real Effective Exchange Rates: Applications to East Asia," paper presented at the Australia-Japan Research Center/China Center for Economic Research conference on "Deepening Financial Arrangements in East Asia," Beijing University, March 24-25, 2002.

Council of Economic Advisers, 2001, Economic Report of the President (Washington, D.C.: U.S. GPO, January).

Goldstein, Morris and Mohsin Khan, 1985, "Income and Price Effects in Foreign Trade," in R. Jones and P. Kenen (eds.), Handbook of International Economics, Vol. 2, (Amsterdam: Elsevier), Chapter 20.

Golub, Stephen, 1994, "Comparative Advantage, Exchange Rates and the Sectoral Trade Balances of the Major Industrial Countries," IMF Staff Papers 41, pp. 286-313.

Hargreaves, Derek, 1993, "Rebasing and Reweighting of J.P. Morgan Effective Exchange Rate Indices," World Financial Markets (New York: J.P. Morgan, Nov. 19), p. 23.

Helkie, William and Peter Hooper, 1988, “The U.S. External Deficit in the 1980's: An Empirical Analysis," in R. Bryant, G. Holtham and P. Hooper (eds.) External Deficits and the Dollar: The Pit and the Pendulum (Washington, DC: Brookings Institution).

Hong, Pingfan, 1999, “Import Elasticities Revisited," Discussion Paper No. 10 (NY: United Nations Department of Economic and Social Affairs, September).

Hooper, Peter, Karen Johnson and Jaime Marquez, 1998, "Trade Elasticities for G-7 Countries," International Finance Discussion Papers No. 609 (Washington, DC, Federal 
Reserve Board, April). Revised version published as Princeton Studies in International Economics No. 87 (Princeton, NJ: Princeton University, 2000).

Houthakker, Hendrik and Stephen Magee, 1969, "Income and Price Elasticities in World Trade," Review of Economics and Statistics 51: 111-25.

Johansen, Søren, 1988, "Statistical Analysis of Cointegrating Vectors," Journal of Economic Dynamics and Control 12: 231-54.

Johansen, Søren, and Katerina Juselius, 1990, "Maximum Likelihood Estimation and Inference on Cointegration - With Applications to the Demand for Money," Oxford Bulletin of Economics and Statistics 52: 169-210.

Johnston, Louis D. and Menzie Chinn, 1996, "How Well Is America Competing? A Comment on Papadakis," Journal of Policy Analysis and Management 15(1) (Winter), pp. $68-81$.

Krugman, Paul, 1989, "Differences in Income Elasticities and Trends in Real exchange Rates," European Economic Review 33: 1031-1054.

Lawrence, Robert Z., 1990, "U.S. Current Account Adjustment: An Appraisal," Brookings Papers on Economic Activity No. 2, pp. 343-382.

Leahy, Michael P., 1998, "New Summary Measures of the Foreign Exchange Value of the Dollar," Federal Reserve Bulletin (October), pp. 811-818.

Mann, Catherine, forthcoming, "Perspectives on the U.S. Current Account Deficit and Sustainability," Journal of Economic Perspectives.

Mann, Catherine, 1999, Is the U.S. Trade Deficit Sustainable? (Washington, DC: IIE).

Meade, Ellen, 1992, "A Fresh Look at the Responsiveness of Trade Flows to Exchange Rates," Paper prepared for the annual meetings of the Western Economic Association, San Francisco, July 9-13 (June 1992).

Meade, Ellen, 1991, "Computers and the Trade Deficit: the case of the falling prices" in P. Hooper and D. Richardson, (eds.) International Economic Transactions: Issues in Measurement and Empirical Research, NBER Studies in Income and Wealth vol. 55.

Rose, Andrew, 1991, "The Role of Exchange Rates in a Popular Model of International Trade: Does the 'Marshall-Lerner' Condition Hold?' Journal of International Economics 30: 301-316.

Rose, Andrew and Janet Yellen, 1989, “Is There a J-Curve?” Journal of Monetary Economics 24, pp. 53-68. 
Whelan, Karl, 2000, "A Guide to the Use of Chain Aggregated NIPA Data," Finance and Economics Discussion Papers 2000-35 (Washington, DC: Board of Governors of the Federal Reserve System, June).

Zanello, Allesandro, and Dominique Desruelle, 1997, “A Primer on IMF's Information Notices System,” Working Paper WP97/71 (Washington, DC: International Monetary Fund). 
Table 1

Johansen Cointegration Results: Imports

\begin{tabular}{|c|c|c|c|c|c|}
\hline \multicolumn{2}{|l|}{ Long Run } & \multicolumn{2}{|c|}{ CPI deflator } & \multicolumn{2}{|c|}{ PPI deflator } \\
\hline Coeff & Pred & $\begin{array}{l}\text { Imports } \\
{[1]}\end{array}$ & $\begin{array}{l}\text { Imports } \\
\text { [2] }\end{array}$ & $\begin{array}{l}\text { Imports } \\
\text { [3] }\end{array}$ & $\begin{array}{l}\text { Imports } \\
\text { [4] }\end{array}$ \\
\hline Trace & & 20.63 & $28.87 *$ & $21.63 * \star$ & $33.94 * *$ \\
\hline$\lambda-\max$ & & 18.04 & $24.66 * *$ & 17.73 & $26.80 \star \star \star$ \\
\hline $\mathrm{CR}^{\prime} \mathrm{s}$ & & 0,0 & 1,1 & 0,0 & 1,1 \\
\hline q & $(-)$ & $\begin{array}{l}-0.177 \\
(0.129)\end{array}$ & $\begin{array}{l}-0.109 \\
(0.087)\end{array}$ & $\begin{array}{l}-0.172 \\
(0.164)\end{array}$ & $\begin{array}{l}-0.184 * \\
(0.094)\end{array}$ \\
\hline$y$ & $(+)$ & $\begin{array}{l}2.288 * * * \\
(0.062)\end{array}$ & $\begin{array}{l}2.099 * \star * \\
(0.062)\end{array}$ & $\begin{array}{l}2.264 * \star * \\
(0.063)\end{array}$ & $\begin{array}{l}2.038 * * \star \\
(0.054)\end{array}$ \\
\hline lag & & 2 & 2 & 2 & 2 \\
\hline $\mathrm{N}$ & & 106 & 106 & 106 & 106 \\
\hline Smpl & & $75 q 1-01 q 2$ & $75 q 1-01 q 2$ & $75 q 1-01 q 2$ & $75 q 1-01 q 2$ \\
\hline Dummies & & & $95 q 1$ & & $95 q 1$ \\
\hline \multicolumn{6}{|c|}{ Reversion coefficients } \\
\hline $\operatorname{Im}$ & $(-)$ & $\begin{array}{l}-0.113 * \star \\
(0.042)\end{array}$ & $\begin{array}{l}-0.177 * * \star \\
(0.053)\end{array}$ & $\begin{array}{l}-0.111^{* * *} \\
(0.040)\end{array}$ & $\begin{array}{l}-0.201 * * * \\
(0.055)\end{array}$ \\
\hline q & $(+)$ & $\begin{array}{l}0.040 \\
(0.050)\end{array}$ & $\begin{array}{l}0.121^{\star} \\
(0.062)\end{array}$ & $\begin{array}{l}0.034 \\
(0.037)\end{array}$ & $\begin{array}{l}0.123 * \star \star \\
(0.050)\end{array}$ \\
\hline y & $(+)$ & $\begin{array}{l}0.019 \\
(0.013)\end{array}$ & $\begin{array}{l}0.019 \\
(0.017)\end{array}$ & $\begin{array}{l}0.016 \\
(0.012)\end{array}$ & $\begin{array}{l}0.012 \\
(0.018)\end{array}$ \\
\hline
\end{tabular}

Notes: "Coeff" is the coefficient from equation (6) or (7). "Pred" indicates predicted sign. "Trace" $(\lambda$-max) is the trace (maximum eigenvalue) test statistic for the null of zero cointegrating vector against the alternative of one. $\mathrm{CR}$ is the number of cointegrating relations implied by the asymptotic critical values for the trace, $\lambda$-max statistics and $10 \%$ significance level. Critical values assume no exogenous regressors. Coefficients are long run parameter estimates from the Johansen procedure described in the text. Lag is the number of lags in the VAR specification of the system. $\mathrm{N}$ is the effective number of observations included in the regression. Smpl is the sample period. Dummies are indicator variables taking on a value of one at the indicated date. ${ }^{*}(* *)[* * *]$ denotes significance at the $10 \%(5 \%)[1 \%]$ level. 
Table 2

Johansen Cointegration Results: Exports

\begin{tabular}{|c|c|c|c|c|c|}
\hline$\overline{\text { Long Run }}$ & & CPI defla & & PPI deflat & \\
\hline Coeff & Pred & $\begin{array}{l}\text { Exports } \\
{[1]}\end{array}$ & $\begin{array}{l}\text { Exports } \\
{[2]}\end{array}$ & $\begin{array}{l}\text { Exports } \\
{[3]}\end{array}$ & $\begin{array}{l}\text { Exports } \\
{[4]}\end{array}$ \\
\hline Trace & & $28.81 *$ & $33.42 * \star$ & $27.86^{*}$ & $30.88 * *$ \\
\hline$\lambda-\max$ & & $21.31 * *$ & $27.59 * \star \star$ & $21.77 \star \star$ & 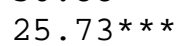 \\
\hline $\mathrm{CR}^{\prime} \mathrm{S}$ & & 1,1 & 1,1 & 1,1 & 1,1 \\
\hline q & $(+)$ & $\begin{array}{l}0.798 * \star \star \\
(0.185)\end{array}$ & $\begin{array}{l}0.702 * \star \star \\
(0.114)\end{array}$ & $\begin{array}{l}0.871 * \star \star \\
(0.173)\end{array}$ & $\begin{array}{l}0.774 * \star \star \\
(0.118)\end{array}$ \\
\hline y & $(+)$ & $\begin{array}{l}1.865 * * * \\
(0.075)\end{array}$ & $\begin{array}{l}1.659 * \star \star \\
(0.068)\end{array}$ & $\begin{array}{l}1.997 * \star \star \\
(0.059)\end{array}$ & $\begin{array}{l}1.834 * \star * \\
(0.059)\end{array}$ \\
\hline lag & & 2 & 2 & 2 & 2 \\
\hline $\mathrm{N}$ & & 106 & 106 & 106 & 106 \\
\hline Smpl & & $75 q 1-01 q 2$ & $75 q 1-01 q 2$ & $75 q 1-01 q 2$ & $75 q 1-01 q 2$ \\
\hline Dummies & & & $95 q 1$ & & $95 q 1$ \\
\hline
\end{tabular}

Reversion coefficients

\begin{tabular}{|c|c|c|c|c|c|}
\hline Im & $(-)$ & $\begin{array}{l}-0.096 * \star \star \\
(0.021)\end{array}$ & $\begin{array}{l}-0.159 \star \star \star \\
(0.030)\end{array}$ & $\begin{array}{l}-0.109 * \star \star \\
(0.026)\end{array}$ & $\begin{array}{l}-0.167 \star \star \star \\
(0.034)\end{array}$ \\
\hline q & $(-)$ & $\begin{array}{l}-0.015 \\
(0.032)\end{array}$ & $\begin{array}{l}-0.012 \\
(0.046)\end{array}$ & $\begin{array}{l}-0.017 \\
(0.031)\end{array}$ & $\begin{array}{l}-0.018 \\
(0.042)\end{array}$ \\
\hline $\mathrm{Y}$ & $(+)$ & $\begin{array}{l}0.002 \\
(0.004)\end{array}$ & $\begin{array}{l}-0.001 \\
(0.006)\end{array}$ & $\begin{array}{l}0.008 \\
(0.005)\end{array}$ & $\begin{array}{l}0.007 \\
(0.007)\end{array}$ \\
\hline
\end{tabular}

Notes: "Coeff" is the coefficient from equation (6) or (7). "Pred" indicates predicted sign. "Trace" $(\lambda$-max $)$ is the trace (maximum eigenvalue) test statistic for the null of zero cointegrating vector against the alternative of one. CR is the number of cointegrating relations implied by the asymptotic critical values for the trace, $\lambda$-max statistics and $10 \%$ significance level. Critical values assume no exogenous regressors. Coefficients are long run parameter estimates from the Johansen procedure described in the text. Lag is the number of lags in the VAR specification of the system. $\mathrm{N}$ is the effective number of observations included in the regression. Smpl is the sample period. Dummies are indicator variables taking on a value of one at the indicated date. $\left.{ }^{* * *}\right)[* * *]$ denotes significance at the $10 \%(5 \%)[1 \%]$ level. 
Table 3

Johansen Cointegration Results: Unit Labor Cost Deflator

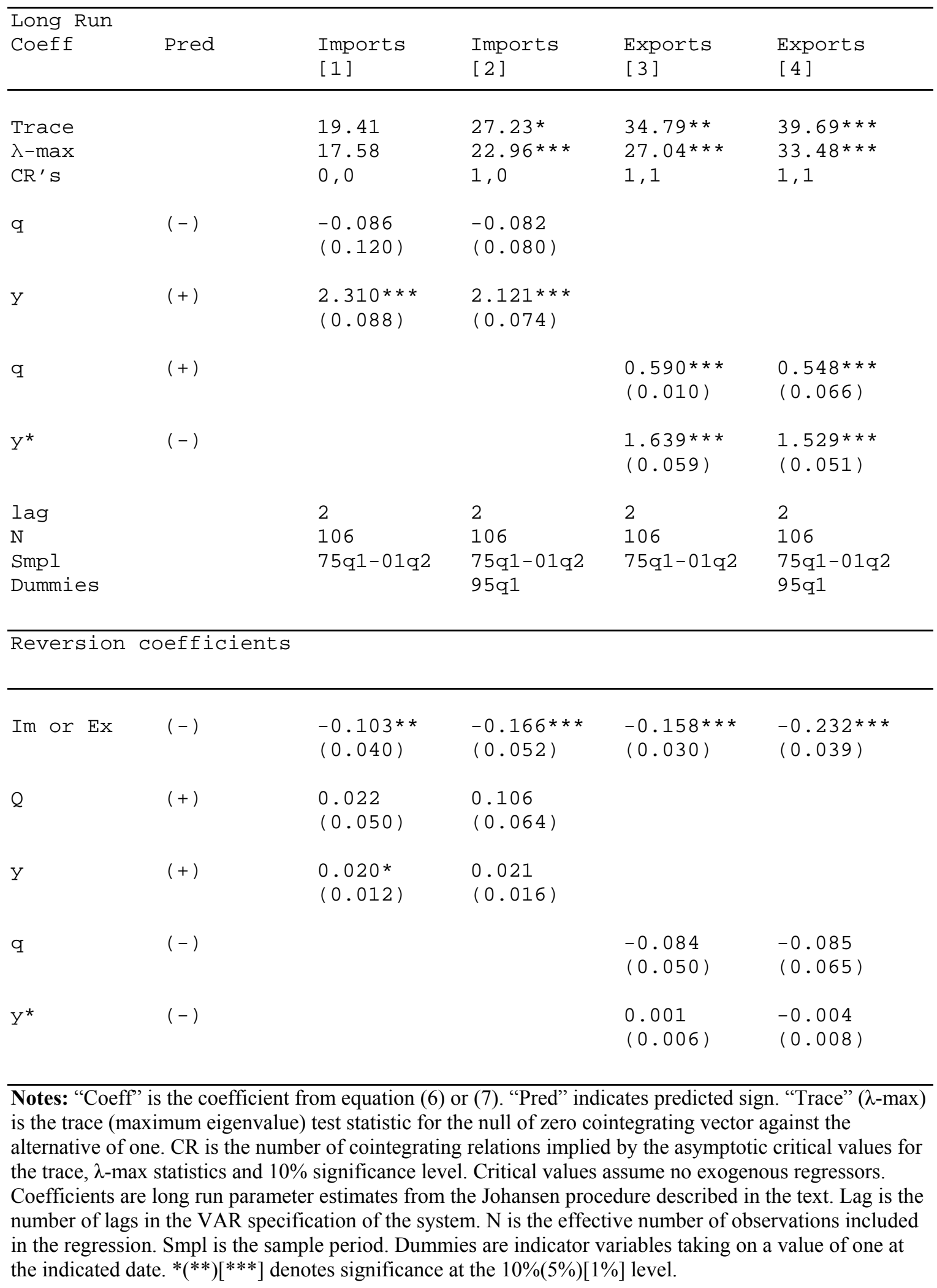


Table 4

Johansen Cointegration Results:

Non-Computer and Computer Imports

\begin{tabular}{|c|c|c|c|c|c|}
\hline $\begin{array}{l}\text { Long Run } \\
\text { Coeff }\end{array}$ & $\begin{array}{l}\text { Noncomputer } \\
\text { Imports } \\
{[1]}\end{array}$ & $\begin{array}{l}\text { Noncomputer } \\
\text { Imports } 1 / \\
{[2]}\end{array}$ & $\begin{array}{l}\text { Noncomputer } \\
\text { Imports } \\
\text { [3] }\end{array}$ & $\begin{array}{l}\text { Noncomputer } \\
\text { Imports } \\
{[4]}\end{array}$ & $\begin{array}{l}\text { Computer } \\
\text { Imports } \\
{[5]}\end{array}$ \\
\hline Trace & 23.23 & 20.26 & $48.34 * *$ & $26.93 *$ & $29.60 *$ \\
\hline$\lambda-\max$ & $19.14 *$ & $18.40 t$ & $25.71 *$ & $20.80 *$ & 16.43 \\
\hline $\mathrm{CR}^{\prime} \mathrm{s}$ & 0,1 & 0,0 & 2,2 & 1,1 & 1,0 \\
\hline q & $\begin{array}{l}-0.225 \\
(0.134)\end{array}$ & $\begin{array}{l}-0.131 \\
(0.101)\end{array}$ & $\begin{array}{l}-1.467 \\
(0.944)\end{array}$ & $\begin{array}{l}-0.295 * \star \\
(0.136)\end{array}$ & $\begin{array}{l}3.738 * * * \\
(0.800)\end{array}$ \\
\hline $\mathrm{y}$ & $\begin{array}{l}2.009 * * * \\
(0.052)\end{array}$ & $\begin{array}{l}2.085 * \star * \\
(0.074)\end{array}$ & $\begin{array}{l}15.228 * * \\
(3.945)\end{array}$ & $\begin{array}{l}1.994 * * * \\
(0.049)\end{array}$ & $\begin{array}{l}10.132 * * \star \\
(0.437)\end{array}$ \\
\hline trend & & & $\begin{array}{l}0.134 * * * \\
(0.030)\end{array}$ & & \\
\hline Spec. & $\begin{array}{l}\text { trend } \\
\text { In data }\end{array}$ & $\begin{array}{l}\text { trend } \\
\text { in data }\end{array}$ & $\begin{array}{l}\text { trend in } \\
\text { coint.vec. }\end{array}$ & $\begin{array}{l}\text { trend in } \\
\text { data }\end{array}$ & $\begin{array}{l}\text { trend in } \\
\text { data }\end{array}$ \\
\hline lag & & 2 & 4 & 4 & 2 \\
\hline $\mathrm{N}$ & 106 & 106 & 106 & 106 & \\
\hline $\begin{array}{l}\text { Smpl } \\
\text { Dummies }\end{array}$ & $75 q 1-01 q 2$ & $75 q 1-01 q 2$ & $75 q 1-01 q 2$ & $75 q 1-01 q 2$ & $87 q 3-01 q 2$ \\
\hline \multicolumn{6}{|c|}{ Reversion coefficients } \\
\hline $\operatorname{Im}$ & $\begin{array}{l}-0.151 * \star \star \\
(0.046)\end{array}$ & $\begin{array}{l}-0.135 * \star \\
(0.045)\end{array}$ & $\begin{array}{l}-0.029 * \star \star \\
(0.006)\end{array}$ & $\begin{array}{l}-0.159 * \star \star \\
(0.048)\end{array}$ & $\begin{array}{l}0.031 \\
(0.036)\end{array}$ \\
\hline q & $\begin{array}{l}0.054 \\
(0.043)\end{array}$ & $\begin{array}{l}0.043 \\
(0.058)\end{array}$ & $\begin{array}{l}0.003 \\
(0.006)\end{array}$ & $\begin{array}{l}0.022 \\
(0.046)\end{array}$ & $\begin{array}{l}0.067 * \star \star \\
(0.020)\end{array}$ \\
\hline Y & $\begin{array}{l}0.011 \\
(0.015)\end{array}$ & $\begin{array}{l}0.017 \\
(0.014)\end{array}$ & $\begin{array}{l}-0.005 * \star \\
(0.002)\end{array}$ & $\begin{array}{l}0.015 \\
(0.015)\end{array}$ & $\begin{array}{l}0.010 * * \\
(0.005)\end{array}$ \\
\hline \multicolumn{6}{|c|}{$\begin{array}{l}\text { Notes: "Coeff" is the coefficient from equation (6) or (7). "Pred" indicates predicted sign. "Trace" }(\lambda \text {-max) } \\
\text { is the trace (maximum eigenvalue) test statistic for the null of zero cointegrating vector against the } \\
\text { alternative of one. CR is the number of cointegrating relations implied by the asymptotic critical values for } \\
\text { the trace, } \lambda \text {-max statistics and } 10 \% \text { significance level. Coefficients are long run parameter estimates from } \\
\text { the Johansen procedure described in the text. Spec. is the specification of the vector error correction } \\
\text { model; "trend in data" indicates a trend in the data, but not the cointegrating vector, is allowed for. "trend } \\
\text { in cointegrating vector" indicates that a trend is allowed for in the long run relationship. "quadratic trend" } \\
\text { allows a deterministic quadratic trend in the cointegrating vector. Lag is the number of lags in the VAR } \\
\text { specification of the system. N is the effective number of observations included in the regression. Smpl is } \\
\text { the sample period. Dummies are indicator variables taking on a value of one at the indicated date. } \\
{ }^{*}(* *)[* * *] \text { denotes significance at the } 10 \%(5 \%)[1 \%] \text { level. } \\
{ }^{1} \text { Using unit labor cost deflated measure of real exchange rate. }\end{array}$} \\
\hline
\end{tabular}


Table 5

\section{Comparison of Some Recent Elasticity Estimates}

\section{Panel 5.1: Imports}

\begin{tabular}{|c|c|c|c|c|}
\hline $\begin{array}{l}\text { Long Run } \\
\text { Coeff. }\end{array}$ & $\begin{array}{l}\text { Hooper } \\
\text { et al. } \\
(1998) \\
{[1]}\end{array}$ & $\begin{array}{l}\text { Boyd 1' } \\
\text { et al. } \\
(2001) \\
{[2]}\end{array}$ & $\begin{array}{l}\text { Chinn'2 } \\
\text { total } \\
\text { [3] }\end{array}$ & $\begin{array}{l}\text { Chinn²/ } \\
\text { ex. Comp. } \\
{[4]}\end{array}$ \\
\hline q & $\begin{array}{l}0.11 \text { to } \\
0.13\end{array}$ & -1.42 & -0.184 & -0.295 \\
\hline $\mathrm{y}$ & $\begin{array}{l}2.11 \text { to } \\
2.22\end{array}$ & 0.45 & 2.038 & 1.994 \\
\hline $\begin{array}{l}\text { Smpl } \\
\text { Dummies }\end{array}$ & $1960-94$ & $1970-95$ & $\begin{array}{l}1975-2001 \\
1995\end{array}$ & $1975-2001$ \\
\hline \multicolumn{5}{|c|}{ Reversion coefficients } \\
\hline $\operatorname{Im}$ & $\begin{array}{l}0.04 \text { to } \\
-0.10\end{array}$ & -0.238 & -0.201 & -0.159 \\
\hline
\end{tabular}

\section{Panel 5.2: Exports}

\begin{tabular}{|c|c|c|c|c|}
\hline Long Run & $\begin{array}{l}\text { Hooper } \\
\text { et al. } \\
(1998) \\
{[1]}\end{array}$ & $\begin{array}{l}\text { Boyd 1/ } \\
\text { et al. } \\
(2001) \\
{[2]}\end{array}$ & $\begin{array}{l}\text { Chinn'2 } \\
\text { total } \\
{[3]}\end{array}$ & $\begin{array}{l}\text { Chinn } \\
\text { total } \\
{[4]}\end{array}$ \\
\hline q & $\begin{array}{l}0.52 \text { to } \\
0.72\end{array}$ & 1.42 & 0.871 & 0.590 \\
\hline $\mathrm{y}$ & $\begin{array}{l}1.68 \text { to } \\
1.81\end{array}$ & 0.65 & 1.997 & 1.639 \\
\hline $\begin{array}{l}\text { Smpl } \\
\text { Dummies }\end{array}$ & $1960-94$ & $1970-95$ & $1975-2001$ & $1975-2001$ \\
\hline \multicolumn{5}{|c|}{ Reversion coefficients } \\
\hline $\mathrm{Ex}$ & $\begin{array}{l}-0.20 \text { to } \\
-0.35\end{array}$ & -0.238 & -0.209 & -0.158 \\
\hline
\end{tabular}

Notes: "Coeff" is long run parameter estimates from the Johansen procedure described in the text. Real exchange rate index is unit labor cost deflated, unless otherwise noted. "Reversion" is the reversion coefficient for the relevant trade flow. Source: Hooper et al. (1998), Boyd et al. (2001) and author's calculations.

1/ Imports and export exchange rate elasticities constrained to be equal and opposite.

2/ Uses PPI deflated real exchange rate index. 


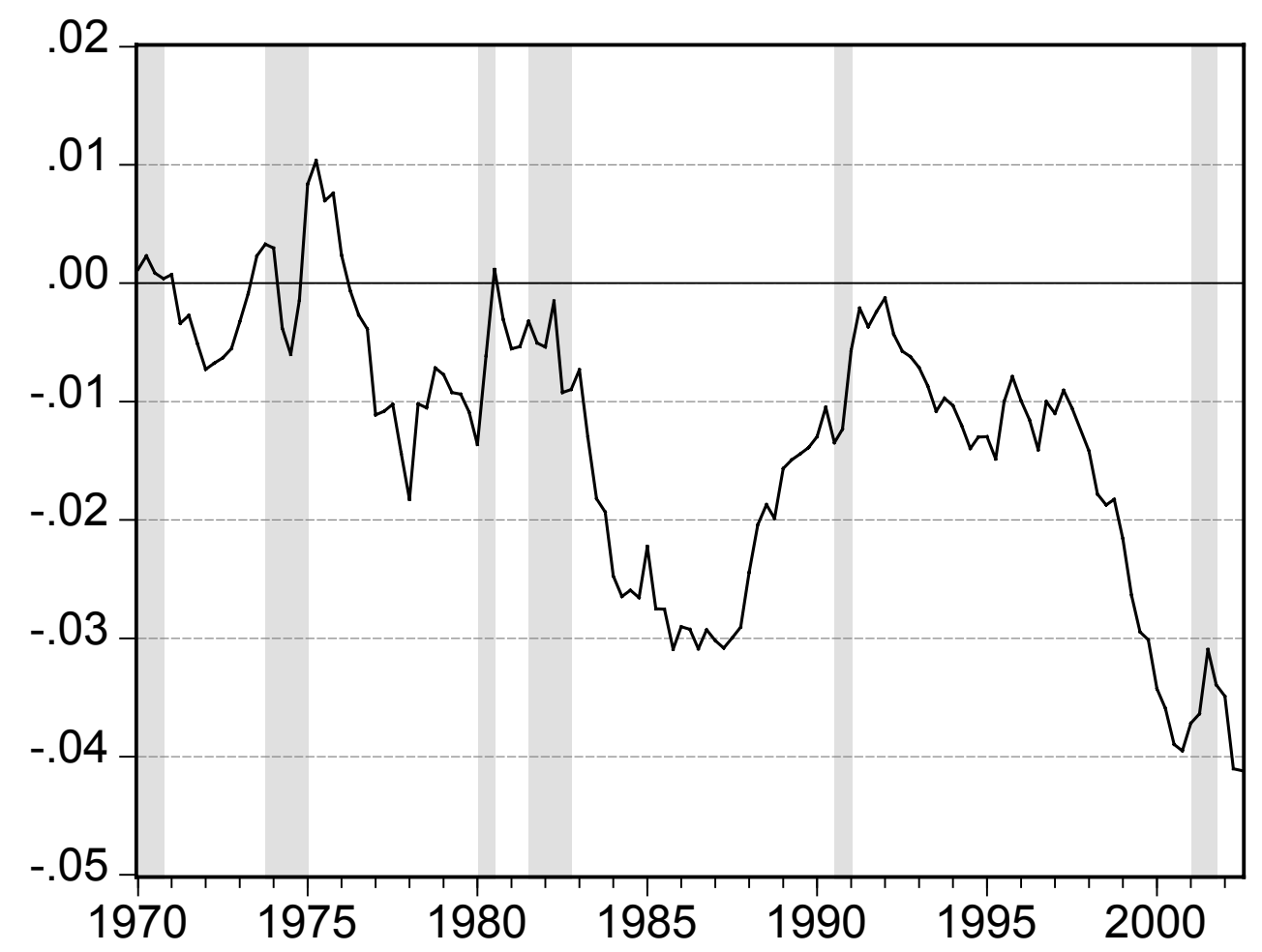

Figure 1: Nominal U.S. Trade Balance to GDP ratio (SAAR). Source: BEA (National income and product accounts, Nov. 26, 2002), and NBER for recession dates. The end date for the last recession is the author's estimate. 


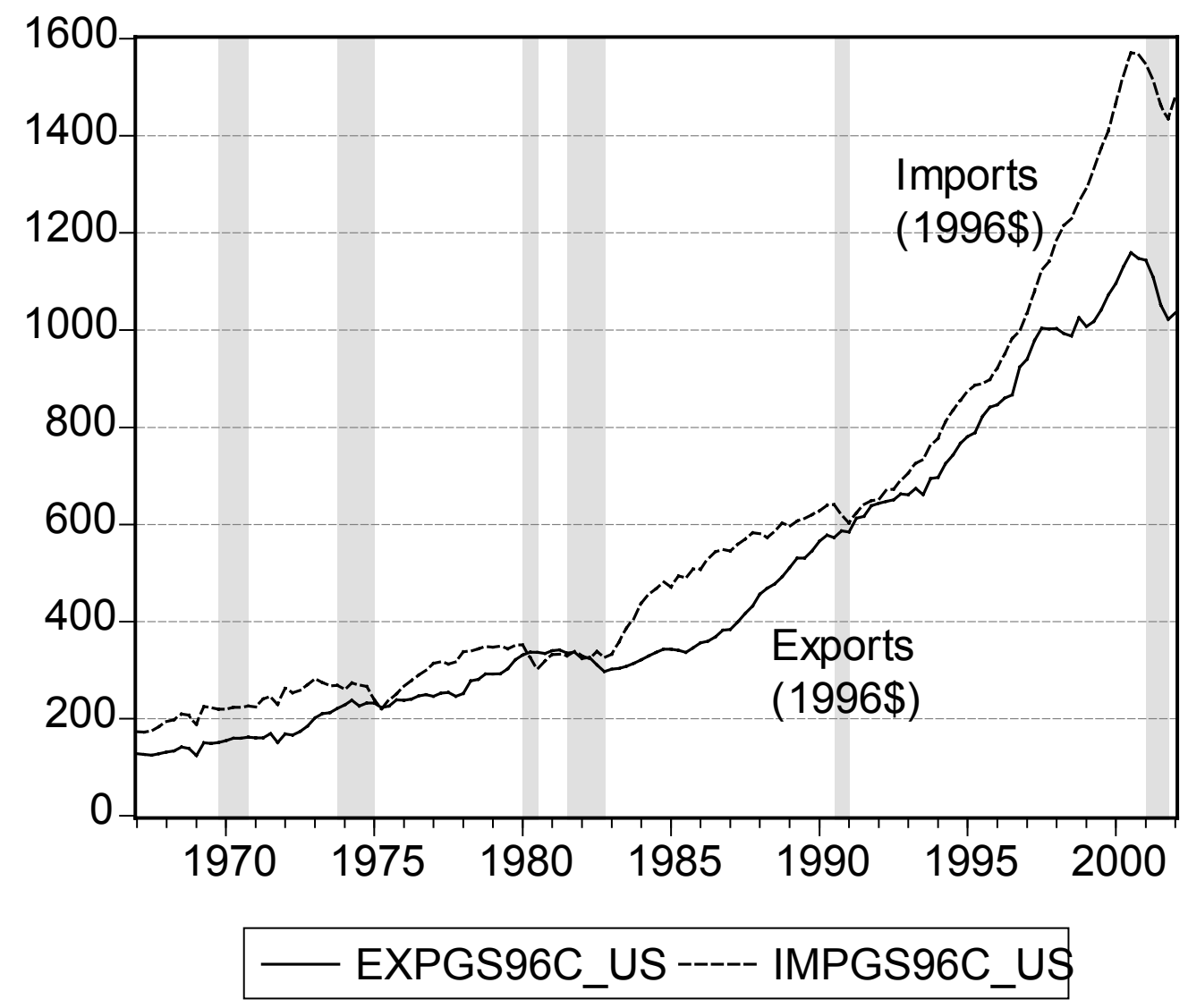

Figure 2: Exports and Imports of Goods and Services, in chained 1996\$. Source: BEA. 


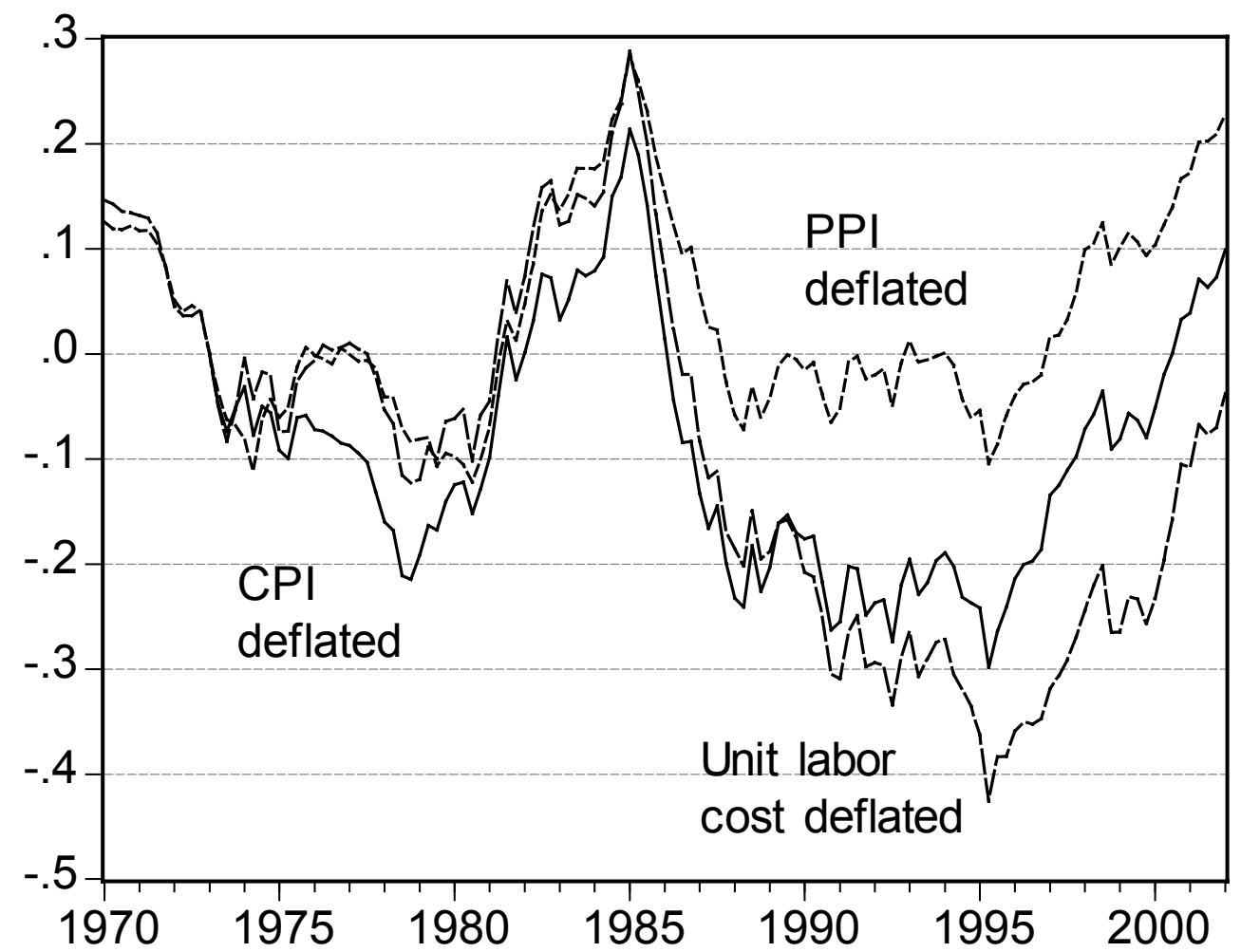

Figure 3: Indices of the U.S. Dollar Effective Exchange Rate. Source: Federal Reserve Board, J.P. Morgan and IMF. 


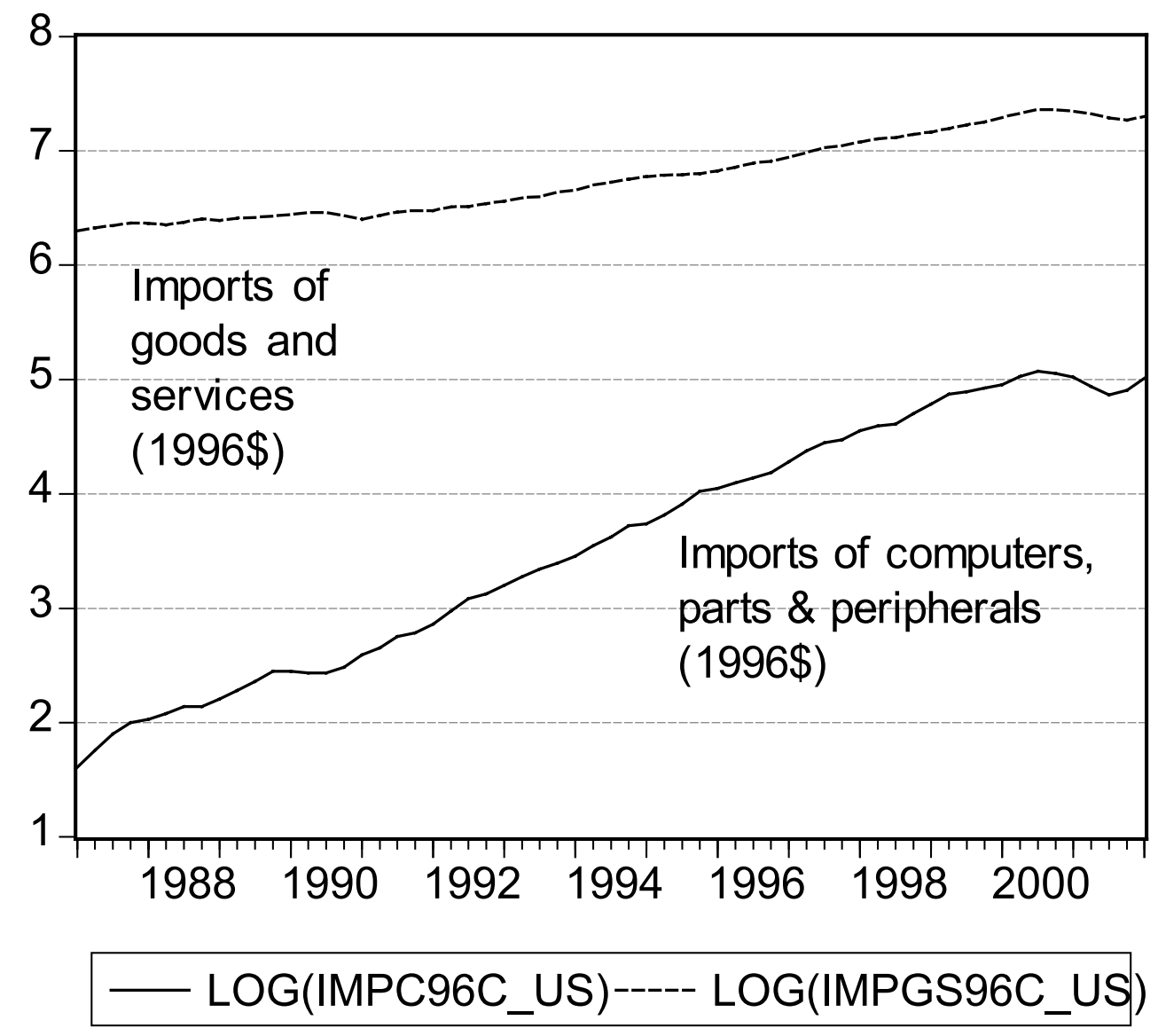

Figure 4: Log Imports of Computers, Parts and Peripherals, and Imports of Goods and Services, in Chained 1996\$. Source: BEA. 


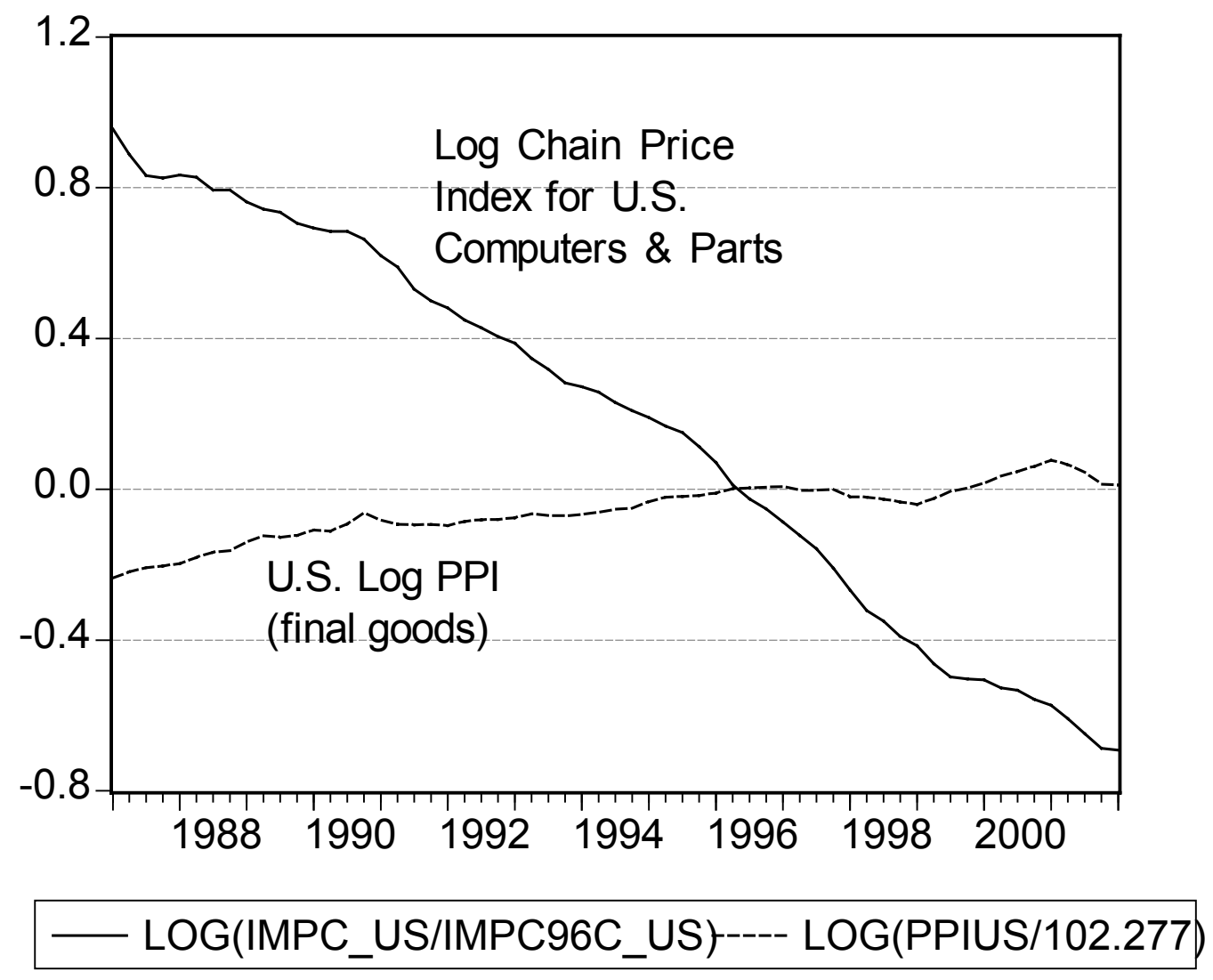

Figure 5: Log Chain Index Price of Computer Imports and U.S. PPI. Source: Author's calculations and IMF. 


\section{Appendix 1: Data Sources and Description}

\section{Exchange Rate Indices}

- US “Major" trade weighted exchange rate (CPI deflated). Source: Federal Reserve Board website, http://www.federalreserve.gov/releases/h10/Summary/indexnc_m.txt . Weights are listed at http://www.federalreserve.gov/releases/h10/Weights/ . Data accessed June $29^{\text {th }}$. See Leahy (1998) for details.

- "Broad" trade-weighted real exchange rates (PPI-deflated). 1990=100, 1990 trade weights for 1987-2001; 1980 trade weights for 1970-86 (weights exclude China). Hong Kong series adjusted by Hong Kong retail price index. Source: J.P. Morgan, http://www2.jpmorgan.com/MarketDataInd/Forex/REXB.bin. Data accessed June 29th. For a description of the series construction, see Hargreaves (1993).

- Trade-weighted real exchange rates (unit labor cost-deflated). 1995=100, 19881990 trade weights. Source: International Financial Statistics May 2002 CDROM, line reu, for 1978q1-2002q1 sample. Series spliced to previous reu series $(1985=100)$, accessed in 1994. Unit labor costs are filtered using the HP filter. See Zanello and Desruelle (1997) for details.

\section{Trade Flows, Economic Activity}

- Real imports and exports of goods and services (1996 chain weighted dollars). Source: Federal Reserve Bank of St. Louis (FRED) website.

- Real imports and exports of non-computer goods and services, and of noncomputer goods (1996 chain weighted dollars). Source: personal communication from BEA, and post-1987, calculated using Tornqvist approximation. See Whelan (2000) for an explanation of the procedure. Computer imports before 1987 are measured using fixed weight measures (the difference between chain weighted and fixed weighted imports was minor in 1987q1), extending back to 1970. For observations recorded as NA, it was assumed computer imports were $\$ 0.05$ billion. 
- U.S. GDP (1996 chain weighted dollars). Source: Federal Reserve Bank of St. Louis (FRED) website.

- Rest-of-World GDP (1996 dollars). U.S. exports weighted rest-of-world GDP. Source: personal communication from Federal Reserve. Updated over 2000q3$2001 \mathrm{q} 4$ period using regression on country trading partner GDP; $\mathrm{R}^{2}$ of regression 0.99 . 


\section{Appendix 2}

\section{Table A1: Disaggregated Results}

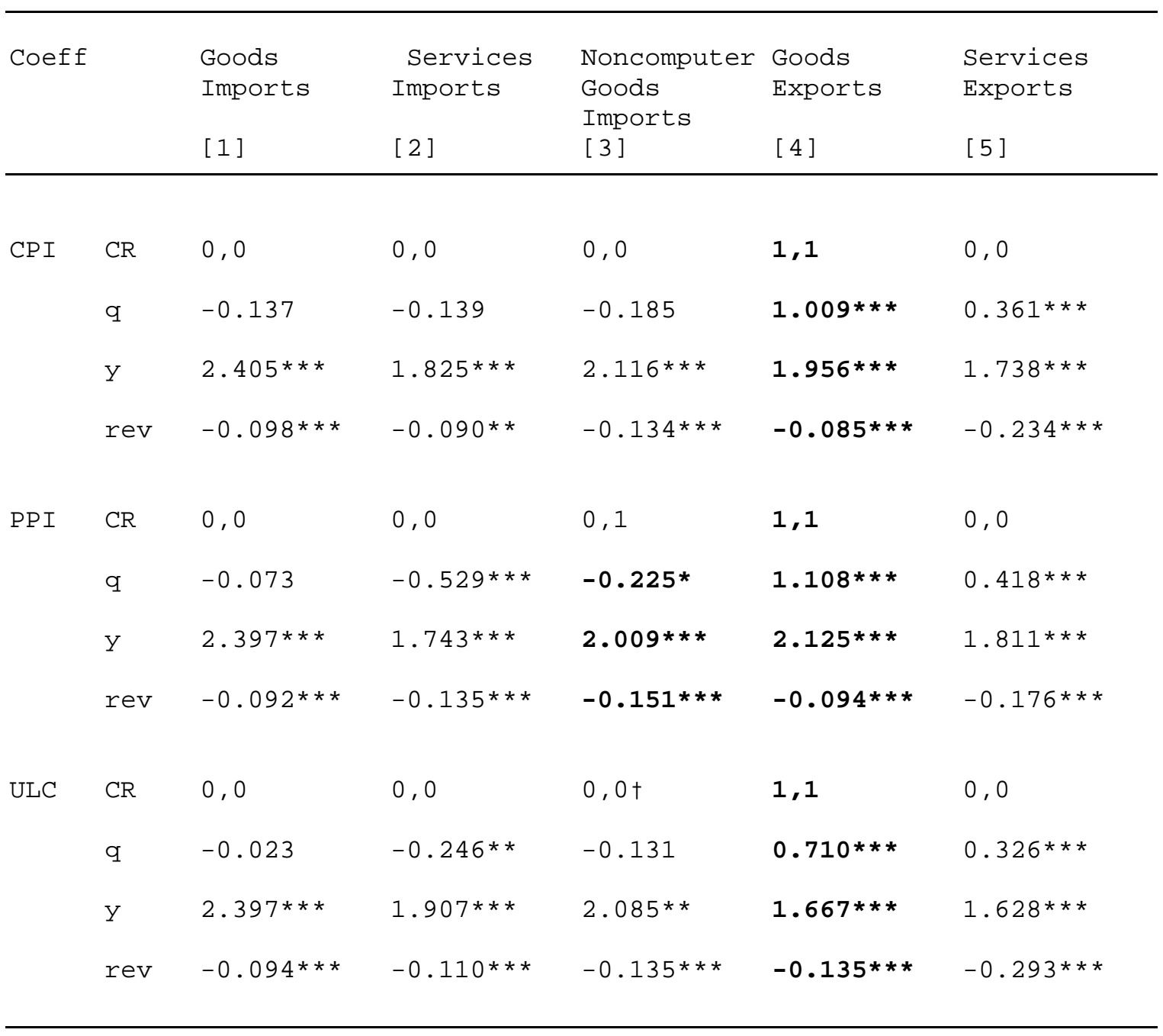

Notes: "Coeff" is the coefficient on the indicated variable (q, y) from equation (6) or (7); "rev" is the reversion coefficient on the trade flow, corresponding to either $\varphi_{1}$ or $\varphi_{4} . \mathrm{CR}$ is the number of cointegrating relations implied by the asymptotic critical values for the trace, $\lambda$-max statistics and $10 \%$ significance level. Coefficients are long run parameter estimates from the Johansen procedure described in the text, a specification allowing a trend in the data, but not the cointegrating vector. Lag length is set at 2 in VAR specification of the system. The sample is 1975q1-2001q2. *(**)[***] denotes significance at the $10 \%(5 \%)[1 \%]$ level.

${ }^{\dagger}$ Denotes borderline significance according to $\lambda$-max statistic. 


\section{Appendix 3 \\ Out-of-Sample Peformance}

The out-of-sample performance of the import and export equations is illustrated in the following graphs. For non-computer imports of goods and services, a specification corresponding to column 4 of Table 4 is estimated over the 1975q1-97q4 period. For exports of goods and services, a specification corresponding to column 3 of Table 2 is estimated over the 1975q1-97q4 period. Static out-of-sample forecasts are depicted in Figures A1 and A2 for imports and exports, respectively. The static forecasts are generated using only the import or export equation; hence, no interactions between the separate equations of the VAR are allowed.

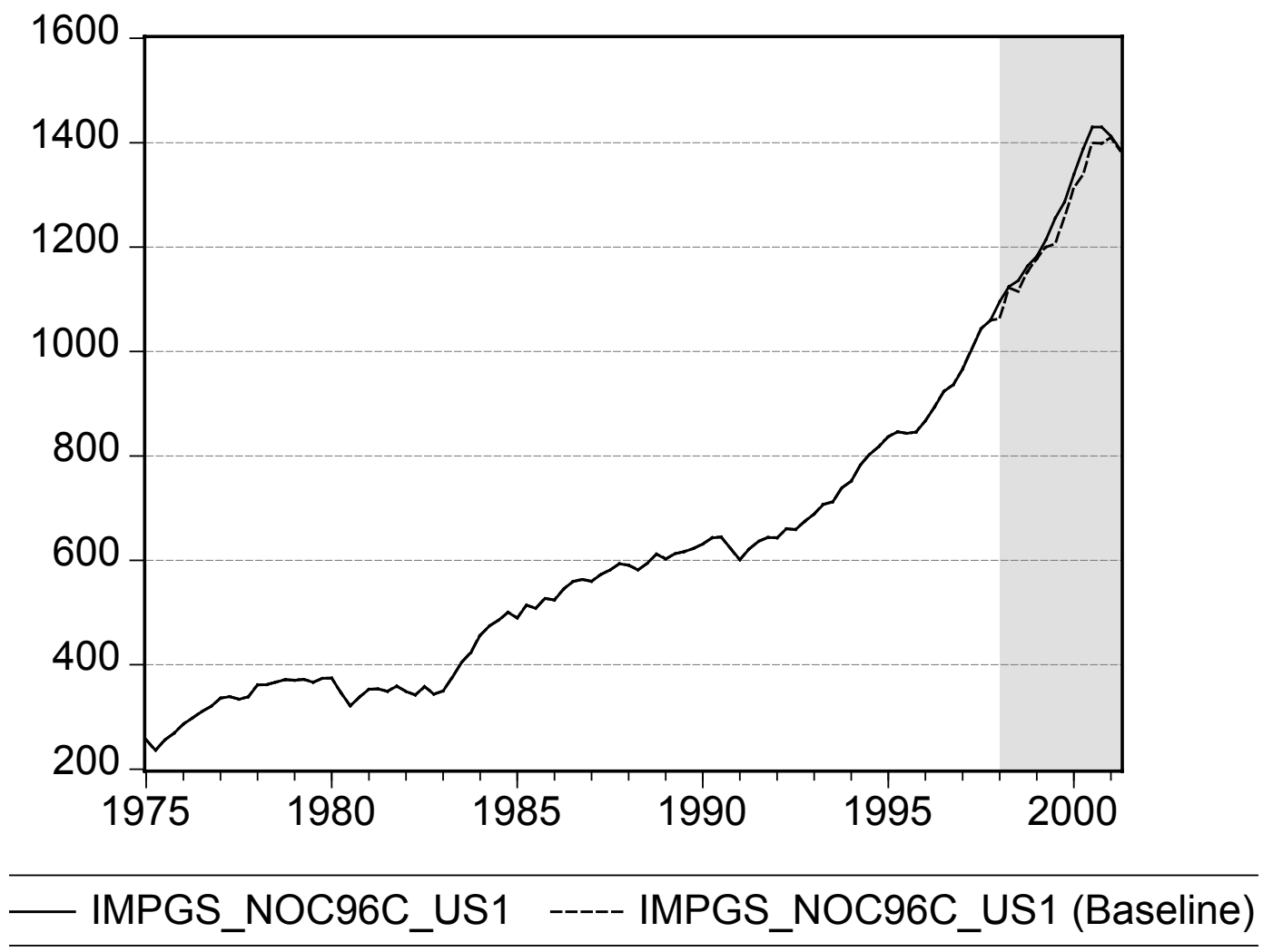

Figure A1: Non-computer Imports of Goods and Services, and Static Forecast, in billions chained 1996\$ 


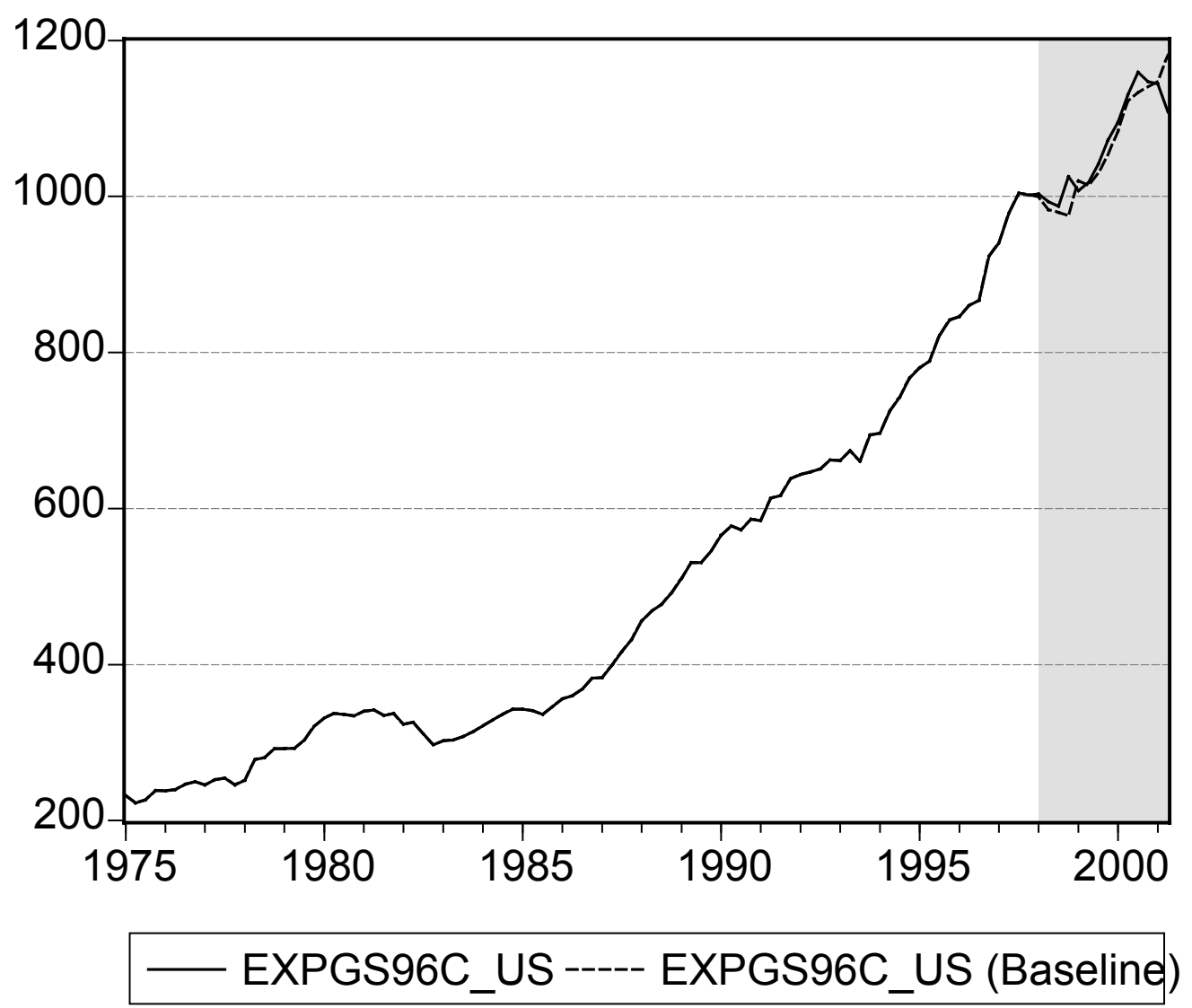

Figure A2: Exports of Goods and Services, and Static Forecast, in chained 1996\$ 